\title{
An Information System Design Product Theory for Student Academic Self-Service University Management System
}

\author{
Muhamad Idaham Umar Ong ${ }^{1}$, Mohamed Ariff Ameedeen ${ }^{1,2}$ \\ ${ }^{1}$ Faculty of Computing, College of Computing and Applied Sciences, Universiti Malaysia Pahang, 26300 Pahang, Malaysia. \\ 2IBM Centre of Excellence, Universiti Malaysia Pahang, Cybercentre, Pahang Tech Park Gambang, 26300 Pahang, Malaysia.
}

\begin{abstract}
The role of Information System Design Theory in software development is enormous. With the help of design theory, developers could estimate how the system will be and reasons why the system react that way. The focus of the article is to revised and re-establish the design theory of a self-service university management system. The objectives of this publication are to identify the most relevant publication that will act as a guideline to generate the design theory artefacts and to establish the artefacts which will consists of three components named kernel theory, meta-requirements and meta-design for the stated system. The system scope will be focused on enabling self-service functions. Validation will be done through FEDS framework with the inclusion of traceability matrix between the meta-requirement against the real-world user requirement. The significant of this article is to provide an initial set of design theory artefacts to be utilization software developer in development or evaluation of a University Management System.
\end{abstract}

ARTICLE HISTORY

Revised: 02 Jan 2021

Accepted: 13 Apr 2021

\section{KEYWORDS}

Software Engineering,

Requirement Engineering,

Information System

Design Theory, University

Management System

\section{INTRODUCTION}

In the tender process, it is common for development teams to invest less time on User Requirement Specification (URS) validation. In the case of a newly proposed development project with the inclusion of URS in the competition phase for the tender, this problem arises. This is due to the time and staffing constraints faced by the team and being handed to the sales department, and for most open tenders, this is normal. And the URS itself is also presented in the use of natural language in a non-formal manner. Most common USR are being presented in the form of natural language such as use case descriptions, user stories, etc. [1]-[5].

Recent author's work [6]-[10] has shown that there are benefits in the introduction of meta-requirement into the world of software development. The use of Information System Design Theory (ISDT) in the evaluation of specifications is advocated in order to address this. The ISDT concept is an attempt to establish the relationships of the proposed that is more or less similar to a previous success deployed project. Design theory must address the question of how to combine components and relationships to make subsystems and how to combine subsystems and relationships to make a system [11].

The first objective of this publication is to identify the most relevant publication that will be used as a guide to the establishment of the revised ISDT component for the University Management System (UMS), in the context of enabling self-service functionality to the main impacted user role "Student". The second objective of this publication is to establish the three revised components of ISDT for the UMS which will be focusing on the stated context. The component that will be established includes the Kernel Theory(s) (KT), meta-requirement(s) (MR) and meta-design(s) (MD) of the ISDT design product. The scope that the ISDT will cover is the academic aspect of the student pre-university life until the end of their study and they are conferred.

The rest of this paper is organized as follows: Section 2 briefly presents the related literatures that assist in the creation of meta-requirements. Section 3 explains the research methodology that was conducted and detailing the involved kernel theories. Section 4 and 5 details the meta-requirements and meta-designs that were generated based on the defined kernel theories. Section 5 describing validation that will be done in future publication. And finally section 6 concludes the publication and future that need to be executed in this research.

\section{RELATED LITERATURE}

This section will describe the literature that is related to this article. Depending on the context itself, Design Theory (DT) is being defined differently by other researchers. The situation of analyzing perspective in pre-project for vendors who have a minimum track record of developing the themed tender project will only be able to rely on predictive input.

Focusing more detail in the knowledge of MR for the use of developing and information systems, we have established an understanding that the work of [11] in the topic of ISDT is the area of interest in our research. The next action, a 
systematic literature review (SLR) was conducted. The relevant publication shows that authors publication related to ISDT repeatedly show interest in establishing the MR, MD and KT of the ISDT. Less interest is being shown for Testable Design Product or Process Hypotheses.

A few potential publications [12]-[14] that is consistent with the scope of this research where; (1) ISDT artefacts are in the most meaningful and comprehensive with in mind of the author commitment towards the knowledge of ISDT and (2) traceability between MR and MD are being define by their respective author. Appendix 2 (which will be published in a separate article) listed the details of the existing publication with publication [15]-[18] show great commitment by the main author towards the knowledge of ISDT. Their works have become the author's main inspiration and reference in the development of DT for the UMS (refer to Figure 1).

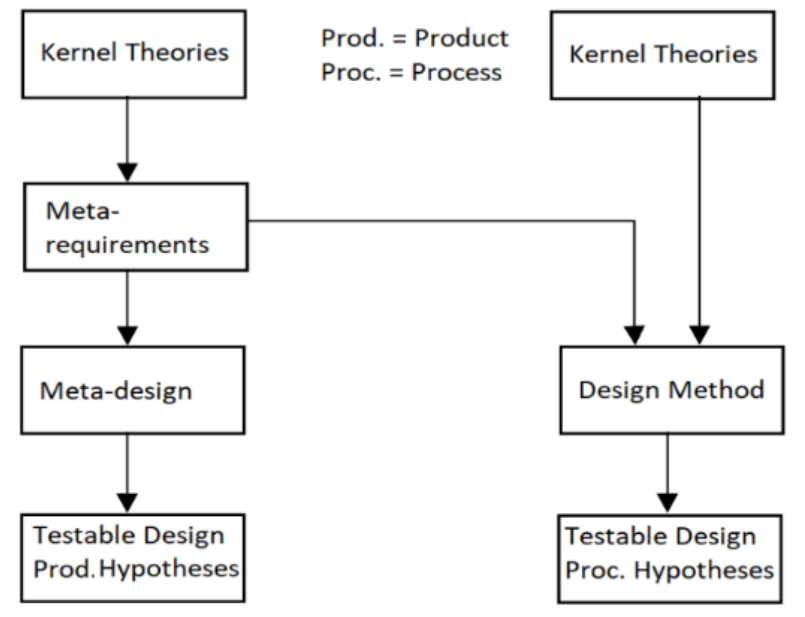

Figure 1. Component of Information System Design Theory [11].

\section{RESEARCH METHODOLOGY AND KERNEL THEORIES}

Focusing on the main role of student, their lifecycle started even before they started registering for the institute of their choice. A breakdown of the overall student lifecycle is being illustrated in Figure 2 and coverage of research is illustrated in Figure 3. In the Student Handbook, the relevant information which align with the design theory of UMS are shown in Table 1.

This research uses a single qualitative case study to provide a whole, systematic understanding of the overall process students will be going through from promotion activities done by the university until they graduate and consider themselves as proud alumni of the university.

Few rounds of engagement were done by the author to investigate the case organization. The case organization was one of public varsities in Malaysia with a strong reputation and matured business process plus evolving it from time-totime based on the need of future generations. It delivers a comprehensive feature in its management system with almost $100 \%$ integration between different departments. The investigation was being conducted on-site. During the investigation, and interviewing was being conducted with key users involving students, the faculty's Deputy Dean of Academic and senior executive of the Academic Management Division to understanding the student's lifecycle and needed feature in the defined scope of UMS.

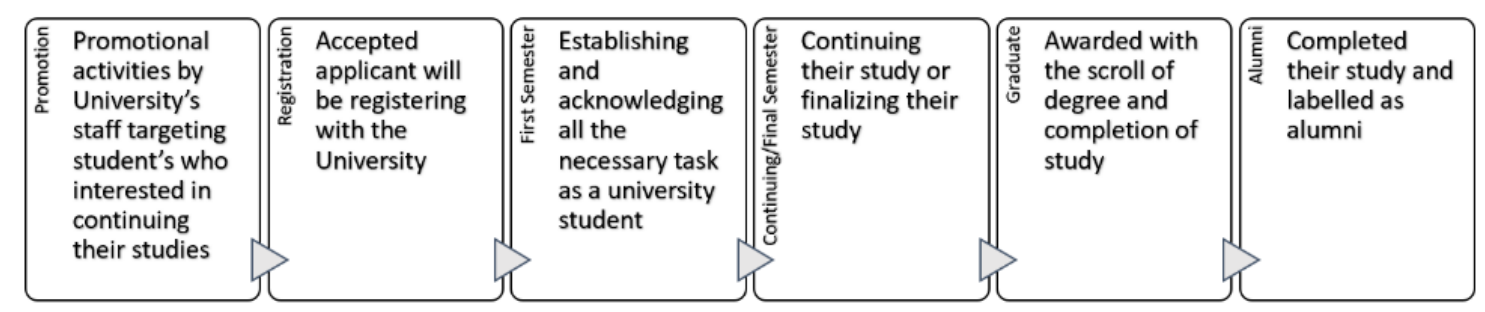

Figure 2. Overall Lifecycle of Diploma/Degree Student 


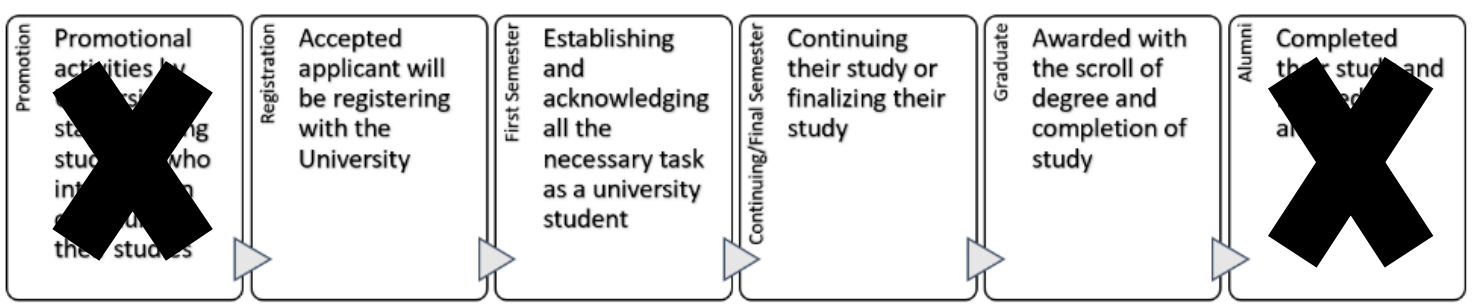

Figure 3. Coverage of ISDT for Sufficient Undergraduate Student Lifecycle

Open-ended discussions are being used with the intention of each session is to produce a feature chart that will be served as both source of KT and also as the MD. After the session is completed, output of the discussion is summarized, and immediate verification and feedback is being provided by interviewees. Several feature charts are being produced on the Student, Academician, Faculty Office and University Office and all the charts are being verified again by the interviewees with addition of making sure that all feature charts are agreed by all parties.

Table 1. Brief description of Student Handbook [19]

\begin{tabular}{|c|c|}
\hline Section Header & Description \\
\hline Definition & Definition of key terms used in the Student Handbook \\
\hline Academic calendar & $\begin{array}{l}\text { The University academic year is divided into two common semesters: Semester I and } \\
\text { Semester II. Each semester comprises } 18 \text { weeks (including lectures, examinations and } \\
\text { preparations }\end{array}$ \\
\hline New student registration & $\begin{array}{l}\text { All student candidates are required to register for the programme offered and pay the } \\
\text { tuition fees on the date set by the University }\end{array}$ \\
\hline Course registration & $\begin{array}{l}\text { Students are required to register for every course that will be taken each semester within } \\
\text { the duration set by the University }\end{array}$ \\
\hline Credit scheme & $\begin{array}{l}\text { Describing that every course has specific credit value and calculation of credit value is } \\
\text { based on SLT or as stipulated by the University, definition of credit hours and matter } \\
\text { pertaining towards maximum and minimum credit hour for the semester which is based } \\
\text { on the students Cumulative Grade Point Average (CGPA) }\end{array}$ \\
\hline $\begin{array}{l}\text { Credit transfer } \\
\text { exemption }\end{array}$ & $\begin{array}{l}\text { Detailing the guidelines of performing credit transfer and exemption for students with } \\
\text { diplomas or certification-based programme }\end{array}$ \\
\hline Grading scheme & $\begin{array}{l}\text { Describing the grading system that is used by the university with detailed explanations } \\
\text { of different levels of marks, common grades and point value. Also its implication } \\
\text { towards the student academic study. }\end{array}$ \\
\hline Assessment & $\begin{array}{l}\text { Rules and regulation on different kind of assessment conducted in the university and } \\
\text { disciplinary actions that will be taken based on student wrongdoing }\end{array}$ \\
\hline Academic status & $\begin{array}{l}\text { Definition of the academic standing of student that is based on their grade point average } \\
\text { (GPA) and CGPA }\end{array}$ \\
\hline Dean's List & $\begin{array}{l}\text { Stating that student with GPA of more than } 3.5 \text { will be eligible to be awarded with } \\
\text { Dean's List }\end{array}$ \\
\hline $\begin{array}{l}\text { Conferment of diploma and } \\
\text { bachelor's degree }\end{array}$ & $\begin{array}{l}\text { Detailing the rules that are applied to students in the process of conferment of diploma } \\
\text { and bachelor's degree. And the different kind of conferment that is being given by the } \\
\text { university }\end{array}$ \\
\hline Study Deferment & $\begin{array}{l}\text { Detailing the different situations that will en'able student to apply for deferment, the } \\
\text { guideline of deferring semester, maximum number of semesters of deferment and its } \\
\text { implication to past and future semester }\end{array}$ \\
\hline Re-registration & Describing the process of student's re-registration process \\
\hline Change of programme & $\begin{array}{l}\text { Stating that students are not permitted to apply for change of programme. Unless with } \\
\text { the exemption from the university senate. }\end{array}$ \\
\hline General Statute & $\begin{array}{l}\text { Stating all the rule, regulation and guideline that are in the Student Handbook must be } \\
\text { abide by all students }\end{array}$ \\
\hline
\end{tabular}

Based on the investigation, the instance of the system includes four main roles: Students, Academicians, Faculty Office and University Office, enabling the solution in managing the complete academic aspect of the student's life cycle. The students are the main stakeholders, by the offering of viewing on-demand academic achievement and overall performance. All input in terms of student performance is being backed by an with the basis of coursework and assessment that was done throughout the active semester period. The Faculty Office will be responsible to control the basis definition of the university academic structure and administrative that involves each semester setup. Graduation of a student is the responsibility of the University Office through student's award. 


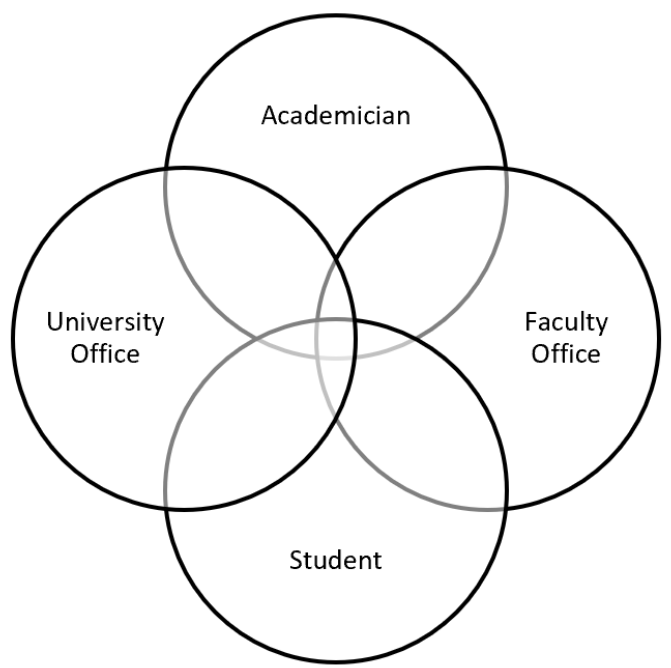

Figure 4. Four UMS User Roles Inter-relationship

The four roles (refer to Figure 4) are inter-related and strongly need to be supporting each other on different degrees of communication. Students and Academicians of colleges are interconnected from the promotional until pre-graduation stages of the student's life cycle. Where else University Offices are involved with the student's life cycle majorly during registration and graduation stages. But all three must be able to coexist with each other to ensure the student's life cycle can be completed. Table 2 describes on a high level the different functionalities of each key role of the UMS.

The design product theory for Student Academic Self-service University Management System based on the defined scope has been generated with reference to the previous work of systematic literature review, documentation related to the organization and student named Academic handbook and the analysis of the features needed of the UMS of the case organization. Based on the three stated sources, the KT that will be used for the generation of other design theory artefacts will be the outcome of the SLR, feature chart based on the interview analysis and academic handbook of the organization, so its processes are likely to create a baseline for theory creation.

Table 2. Responsibilities of Key UMS Roles

\begin{tabular}{ll}
\hline Role & Responsibilities \\
\hline Student & Responsible for completing their studies with reference to the academic study plan that was plotted \\
& by the university and respective schools. Eligibility of different channels of funding for student \\
& application. Completing pre-planned assessments and coursework that was prepared by the \\
& respective school's subject coordinators of each registered subject. To be self-aware of their \\
& performance and progress throughout their study life. Achieving passing results and also awards \\
& along the way in progressing with their study period. Graduate in the field of study. Attending all \\
& classes that they registered. Following the rules and regulation that was stated in the Student \\
& Handbook. Penalize based on academic performance and monetary matters. \\
\hline Academician & $\begin{array}{l}\text { Setting up a teaching and assessment plan for the upcoming semester. Constant input and update } \\
\text { of student's coursework and assessments result. Preparation of multiple types of student's academic } \\
\text { performance report for office use. Allowing and banning of students from assessments and } \\
\text { coursework based on reasons that are academic or disciplinary. }\end{array}$ \\
\hline Faculty Office & Create a systematic mapping of Programme Educational Objectives (PEO), Programme Outcome \\
& (PO), Course Outcome (CO) and Learning Outcome (LO). Composing course catalogue, course \\
timetable and course instructor and coordinator. Preparation of Pre-BOE and BOE reports session \\
at the end of each semester.
\end{tabular}

The abstract and generic nature of the design product theory for Student Academic Self-service University Management System so that software vendors that fit the research problem space can use it to improve their project proposal and gain new insights on the system. It is also possible for the organization that will be required to use a UMS in the future to set their earliest expected outcome of the development through the help of the design product theory.

\section{META-REQUIREMENTS OF THE DESIGN PRODUCT THEORY FOR UNIVERSITY MANAGEMENT SYSTEM}

This section presents the MRs for the design product theory for the class of UMS, which was based on the define KT. Based on the university student handbook, domain experts' interviews and existing relevant publication in the area of ISDT, we are able to formulate a set of MR that describe the UMS in the focused context and will satisfy the defined KT. MR are defined to suit the needs of the students, but at the same time enabling other users such as academicians to provide 
meaningful input towards the system. The following paragraphs detailed the MR for an UMS system. Further explanation and description of the defined MR are being made available as per previous publication.

MR1: UMS shall support the users by provide highly accessible and round the clock self-directed with authorization control and policies and data privacy

It is a necessary feature in modern systems. Systems are needed to be able to serve their function towards its user throughout the day and throughout the night. An online should be able to cater for its user needs by providing a connected and on-demand access to the system at all time with an acceptable amount of performance. This is also being considered as a function that is being taken for granted by most users.

MR2: UMS shall support the users in enabling user empowerment, self-knowledge, self-awareness and selfaccountability through self-management of common responsibilities of a system user

As an organization that will be new to the system that will enable self-service towards its main stakeholders, it is necessary to shift their mind set that all the daily tasks and necessity will be at their fingertip. No longer relying totally on manual face to face routine of results, users are encouraged to be proactive and self-accountable towards the needed result at the end of the day.

MR3: UMS shall support creation and maintenance of student's academic-based artefacts with high dependency and inter-connectivity throughout the system that was defined and standardized by body of governing

All the related artefacts such as student's profile, student's results, student's marks etc. will need to be created and able to be maintained by the staff of the organization. This is essential in making sure that all the necessary requirements for students to graduate from their study are met. The setup and creation of those artefacts are based on the list that is defined by the body of governing.

MR4: UMS shall support the students through enabling and granting access to a set of toolkits in supporting their university life

In the life of a university student, a handful of facilities are being provided in assisting them in their journey to complete their study. Facilities such as library, bursary, faculties and schools, counselling etc. are established by the university. These facilities will also be serving their main purpose of making all inter-related activities within the university run smoothly and efficiently.

MR5: UMS shall support notification, alerts and feedback on critical events in term of rewards, penalties, datelines or achievement related to the user

Time is a critical matter for the students. With their busy lifestyle and keeping up with all assessments that are being given based on the courses that they have registered, the system should be able to alert them of any upcoming and unforeseen events that are happening around the student. Matters that could be related to disciplinary issues which have financial implications towards the student will become a hindrance towards the end of their study life. For example, for them to be able to graduate from the university, they must ensure that all financial matters have been settled.

MR6: UMS shall support interpretation of data for decision makers based of report of single or multitude number of student's performance for pre and post-mortem analysis

This MR is being utilized by all users. With the vast amount of data that the system will accumulate, multiple innovative reports can be produced. The target of this MR is to empower developers to be creative and innovative in developing the different kinds of reports that the system will produce.

MR7: UMS shall support high level of informational authenticity, transparency, traceability, auditability and integrity

All the data that is inside the system must be correct. Each data must be able to be traced back to its origin source even with the evolution that is being forced upon the university. Integrity and transparency of the data must also be at its highest quality. And also must be able to subdue towards different kinds of audit whether internal or external.

MR8: UMS shall support inter-dependencies between different users with different level of authorities in internal and external organization and its defined structure

Different parties are established in a university to manage and endorse the student's course registration, end of semester result and conferment. This will be depending on the university itself. The matters related to the different levels that are needed and the positions that are required to endorse those results are being defined by the university themselves.

MR9: UMS shall support the definition, alignment and chain of communication of the basis organization structural establishment and its evolution in both academia and management

Based on the organization chart and establishment of the university, the system must be able to cater and align with the different kinds of structure that the university is currently using and future changes that it will go through. 
MR10: UMS shall support work-around in handling issues that will potentially hinder the students from completing their study

There will be unforeseen issues that students must face in order for them to graduate from the university. It is stated in the student handbook that they must pass all required courses, achieve CPA of more than 2.00, have applied for conferment and other related requirements. But in order for them to collect the transcript, letter of completion and scroll, they must also make sure that there are non-financial backlogs.

\section{MR11: UMS shall support preliminary, present, progression and end-life of the student lifecycle in variety of status change}

System should be able to change the student status from the start of their registration towards the end of their academic journey. Some of the different status that is tied to the student are Excellent Standing (KC), Good Standing (KB), Probation 1 (P1), Probation 2 (P2) and Fail Standing (KG).

\section{INFORMATION MODEL FOR ACADEMIC SELF-SERVICE UNIVERSITY MANAGEMENT SYSTEM}

This section will describe in detail the MD in the most possible generic level for the purpose of fulfilling the declared MR with reference to the defined KT plus the description on each linkage related to each entity. Further detailed explanation of each MD entity is also described.

\section{Information Model for Academic Self-service University Management System}

In order for us to design a Student Academic Self-service University Management (based on Appendixes 3, 4, 5 and 6 , which will be published in separate articles) in the intention of process centric, the information model for the process must be defined. A model was generated based on the interview input, discussion and feedback of the system. The domain experts of the organization have reviewed and accepted the model. It consists of six elements that are used to integrate the different processes that was established in the organization and purposeful connection are defined between the elements (refer to Figure 6): Student Registration, University Evolution, Continues Evaluation, Results, Endorsing Achievement and Graduation.

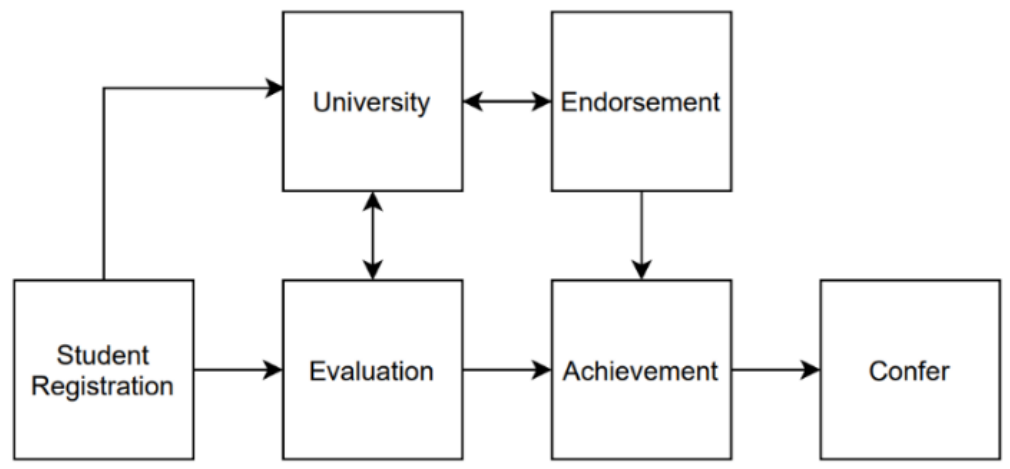

Figure 5. Information Model of the Meta-design of the UMS ISDT

The relationships between entities are explained as follows; (1) Student Registration to University enables the student to be assign to the programme and course that the student need to complete, (2) University to evaluation will be setting up the different method and assessment that the student need to undertake based of the University's programme and course offered, (3) Student Registration to Evaluation will enable the recording of student academic performance, (4) Evaluation to Achievement association will allow generation of student's overall academic performance in preparation of conferment, (5) Endorsement to Achievement is to abide with the common practice of endorsing academic session results by the University, (6) Endorsement to University establish the chain of communication and participant of different level and department involved in the endorsement of results and (7) Achievement to Confer will end the student study lifecycle in the form of award which in transcript, scroll and letter of completion.

\section{Generic Structure of Meta-design Entities}

This section describes the inner content of each MD entity. A generic structure with a defined class based on the work of [16] is applied (definition is being defined in Table 3), which will describe each entity in full clarity. Based on the defined KT and MR, the instance of UMS should at least include these defined structures and attributes (refer to Table 49) based on the defined MD entities in Figure 5.

Table 3. Description of Each Classes in Generic Structure

\begin{tabular}{ll}
\hline Class & Description \\
\hline Description & $\begin{array}{l}\text { Describes the attributes involves that will explain the intent of } \\
\text { and justification for the artefact }\end{array}$ \\
\hline Origin & Describes the attributes involves to origin of the artefact \\
\hline
\end{tabular}




\begin{tabular}{ll}
\hline Analysis & $\begin{array}{l}\text { Describes the attributes involves that has implication towards } \\
\text { the artefact }\end{array}$ \\
\hline Workflow & $\begin{array}{l}\text { Describes the attributes involves that show the subsequent } \\
\text { action or effect towards the artefact }\end{array}$ \\
\hline History & Attributes that keep track of changes towards the artefact
\end{tabular}

University is where the basis of the organization is being established. Commonly, this will be defined and standardized by the body of governing. For example, in Malaysia the organization that is in the responsibility of standardizing, auditing and awarding qualifications for an Institution of Higher Learning is MQA. Schools provide a list of programmes for the students to choose and a list of courses included.

Table 4. Generic Structure of University Artefact

\begin{tabular}{|c|c|c|}
\hline Class & Question & Attributes \\
\hline Description & $\begin{array}{l}\text { What is the University } \\
\text { about? }\end{array}$ & Name, ID, Description, Rationale, Version \\
\hline Origin & $\begin{array}{l}\text { Where does the } \\
\text { University come from? }\end{array}$ & Owner, Source, Date of creation \\
\hline Analysis & $\begin{array}{l}\text { What are the implications } \\
\text { of the University? }\end{array}$ & $\begin{array}{l}\text { Status, ranking, organization educational objective, } \\
\text { offered programmes and courses }\end{array}$ \\
\hline Workflow & $\begin{array}{l}\text { What should be done to } \\
\text { this University next? }\end{array}$ & $\begin{array}{l}\text { Change of organization and body of governance, } \\
\text { evolving to offer better service, improvement toward } \\
\text { knowledge offering, expanding programme, course and } \\
\text { intake, maintain current operation }\end{array}$ \\
\hline History & $\begin{array}{l}\text { What has been done to } \\
\text { the University? When? }\end{array}$ & $\begin{array}{l}\text { Information regarding all previous } \\
\text { edits, changes and person who edits }\end{array}$ \\
\hline
\end{tabular}

Student Registration is used for the creation of an artefact that will serve as the starting point of the system. It is considered as an external source of information that the will system will rely on. Once registered, information will be labeled as an internal source and owned by the organization. This will ensure all the related processes within the system will work seamlessly.

Table 5. Generic Structure of Student Registration Artefact

\begin{tabular}{lll}
\hline Class & Question & Attributes \\
\hline Description & $\begin{array}{l}\text { What is the Student } \\
\text { Registration? }\end{array}$ & Name, ID, Description, Rationale, Version \\
\hline Anigin & $\begin{array}{l}\text { Where does the Student } \\
\text { Registration come from? }\end{array}$ & Owner, Source, Date of creation \\
\hline Workflow & $\begin{array}{l}\text { What are the implications } \\
\text { of the Student } \\
\text { Registration? }\end{array}$ & $\begin{array}{l}\text { Student personal information, academic background, } \\
\text { parents or guardian, financial ledger }\end{array}$ \\
& $\begin{array}{l}\text { What should be done to } \\
\text { this Student Registration } \\
\text { next? }\end{array}$ & $\begin{array}{l}\text { Grant access to facilities, register and attend courses, } \\
\text { completing coursework and final exam, apply for credit } \\
\text { exemption }\end{array}$ \\
\hline History & $\begin{array}{l}\text { What has been done to the } \\
\text { Registration? When? }\end{array}$ & $\begin{array}{l}\text { Information regarding all previous } \\
\text { edits, changes and person who edits }\end{array}$ \\
& &
\end{tabular}

Evaluation handles in recording each of the different kinds of assessment and its result that will be taken by the student. This will require a high level of interconnectivity, authenticity, traceability and transparency.

Table 6. Generic Structure of Evaluation Artefact

\begin{tabular}{lll}
\hline Class & Question & Attributes \\
\hline Description & What is the Evaluation? & Name, ID, Description, Rationale, Version \\
\hline Origin & $\begin{array}{l}\text { Where does the Evaluation } \\
\text { come from? }\end{array}$ & Owner, Source, Date of creation \\
\hline Analysis & $\begin{array}{l}\text { What are the implications } \\
\text { of the Evaluation? }\end{array}$ & Coursework and final exam marks \\
&
\end{tabular}




\begin{tabular}{lll} 
Workflow & $\begin{array}{l}\text { What should be done to this } \\
\text { Evaluation next? }\end{array}$ & $\begin{array}{l}\text { Pass or fail, overall study perform } \\
\text { teaching objective }\end{array}$ \\
\hline History & $\begin{array}{l}\text { What has been done to the } \\
\text { Evaluation? When? }\end{array}$ & $\begin{array}{l}\text { Information regarding all previous } \\
\text { edits, changes and person who edits }\end{array}$
\end{tabular}

Achievement of the student of individual semester and overall study will be used as the basis of continuing study, termination, conferment and other related processes. Different decision-making actions that will require insights based on the evaluation and results will be utilizing this information to its fullest.

Table 7. Generic Structure of Achievement Artefact

\begin{tabular}{lll}
\hline Class & Question & Attributes \\
\hline Description & What is the Achievement? & Name, ID, Description, Rationale, Version \\
\hline Origin & $\begin{array}{l}\text { Where does the } \\
\text { Achievement come from? }\end{array}$ & Owner, Source, Date of creation \\
\hline Analysis & $\begin{array}{l}\text { What are the implications of } \\
\text { the Achievement? }\end{array}$ & $\begin{array}{l}\text { Academic standing, student grades, Dean's List, CPA } \\
\text { and GPA }\end{array}$ \\
\hline Workflow & $\begin{array}{l}\text { What should be done to this } \\
\text { Achievement next? }\end{array}$ & Endorsement result and grade by the university \\
& $\begin{array}{l}\text { What has been done to the } \\
\text { Achievement? When? }\end{array}$ & $\begin{array}{l}\text { Information regarding all previous } \\
\text { edits, changes and person who edits }\end{array}$
\end{tabular}

Endorsement is considered as a common procedure where the different departmental bodies in the university will endorse the achievement of the student for each semester and overall performance through an established chain of communication. The established chain of communication will be differ for each organization and will be based on their own current practice.

Table 8. Generic Structure of Endorsement Artefact

\begin{tabular}{|c|c|c|}
\hline Class & Question & Attributes \\
\hline Description & What is the Endorsement? & Name, ID, Description, Rationale, Version \\
\hline Origin & $\begin{array}{l}\text { Where does the Endorsement } \\
\text { come from? }\end{array}$ & Owner, Source, Date of Creation \\
\hline Analysis & $\begin{array}{l}\text { What are the implications of } \\
\text { the Endorsement? }\end{array}$ & $\begin{array}{l}\text { Endorsement chain of communication, endorsement } \\
\text { list of participants, student CPA and GPA, academic } \\
\text { standing, student conferment }\end{array}$ \\
\hline Workflow & $\begin{array}{l}\text { What should be done to this } \\
\text { Endorsement next? }\end{array}$ & $\begin{array}{l}\text { Student will be either be able to continue study, } \\
\text { terminated, re-register, under probation, defer coming } \\
\text { academic session, apply for change of programme, or } \\
\text { conferment application and collect transcript and letter } \\
\text { of completion }\end{array}$ \\
\hline
\end{tabular}

$\begin{array}{ll}\text { History } & \text { What has been done to the } \\ \text { Endorsement? When? } & \text { edits, changes and person who edits }\end{array}$

Confer will mark the end of the student journey and its information. It will also become a reference for future action that is initiated by the student. For example, organizations that handle the students who are furthering their study on a different level will be able to make use of those information for ease of registration process.

Table 9. Generic Structure of Confer Artefact

\begin{tabular}{lll}
\hline Class & Question & Attributes \\
\hline Description & What is the Confer? & Name, ID, Description, Rationale, Version \\
\hline Origin & $\begin{array}{l}\text { Where does the Confer come } \\
\text { from? }\end{array}$ & Owner, Source, Date of Graduation \\
\hline
\end{tabular}




\begin{tabular}{ll} 
Analysis & $\begin{array}{l}\text { What are the implications of Date of completion, overall study performance } \\
\text { the Confer? }\end{array}$ \\
\hline Workflow & $\begin{array}{l}\text { What should be done to this } \\
\text { Confer next? }\end{array}$ \\
\hline History & $\begin{array}{l}\text { What has been done to the } \\
\text { Confer? When? }\end{array}$
\end{tabular}

\section{VALIDATING AND SCOPING THE DESIGN PRODUCT THEORY}

The method of FEDS Framework [20] has been chosen as the main guidance of the research evaluation based on the well clear defined process. FEDS Framework is being designed to be used in a DSR project, certain calibration will be implemented to adapt the framework to the research purpose. Only the most relevant steps and process of the framework will be utilized for the purpose of evaluating the research Design Theory. Furthermore, in-depth work processes that need to be executed will be referring to other works of researchers. This will complement the main research purpose and also produce a novel method of executing the research evaluation. Further publication will explain the step by step of usage of FEDS Framework in decision making of the novel evaluation method that will accommodate the need of this research. This will be the contribution of the research, whereby the mention calibration is through the utilization of Software Traceability [21] knowledge area in the FEDS Framework for the purpose of making it more inline with the common practice software development project.

\section{CONCLUSION AND FUTURE RESEARCH}

The main objective of this publication is presented based on the UMS design theory. The main contribution of this publication is (1) presenting the most relevant publication that has served as the main guideline of this research and (2) presenting the set of MR and an MD of a UMS, focusing on self-service enabling for students. It is an earliest indication of how the UMS should be, with the utilization of ISDT focusing on the aspect of enabling self-service. With this, it could help software houses to propose, implement or evaluate a management system for a university. Software houses could use the theory (1) to ensure the critical needs are established, (2) to evaluate on the correctness and consistency of future similar theme projects.

Limitation of this publication is the artefacts does not represent the UMS as a whole, but only focused on the part of the student's need of a self-service system and also the other parties that will impact and impacting the different outcome of the student's study life. Also, the publication does not cover the Testable Design Product Hypotheses and the process component of the ISDT (Design Method and Testable Design Process Hypotheses).

Future research will be to calibrate the established artefacts by performing a consistency analysis by referring to the real-requirement and scientifically proven through a comprehensive experimentation that will be established as a means to proving the effectiveness of our initiative.

\section{ACKNOWLEDGEMENT}

This work was supported in part by Grant RDU191802-2.

\section{REFERENCES}

[1] I. Graham, Requirements Engineering and Rapid Development. Addison Wesley, 1998.

[2] S. Lauesen, Software Requirements: Style and Techniques, no. January 2002. Addison-Wesley, 2002.

[3] M. Luisa, F. Mariangela, and N. I. Pierluigi, "Market research for requirements analysis using linguistic tools," Requir. Eng., vol. 9, no. 1, pp. 40-56, May 2004.

[4] A. S. Lokman and M. A. Ameedeen, "Modern Chatbot Systems: A Technical Review," Springer, Cham, 2019, pp. 10121023.

[5] Sutarman, M. B. A. Majid, J. B. M. Zain, and A. Hermawan, "Recognition of Malaysian Sign Language using skeleton data with Neural Network," in 2015 International Conference on Science in Information Technology (ICSITech), 2015, pp. 231236.

[6] M. I. U. Ong and M. A. Ameedeen, “Meta-Requirement Mapping Model,” IOP Conf. Ser. Mater. Sci. Eng., vol. $769,2020$.

[7] M. I. U. Ong, M. A. Ameedeen, and I. E. Kamarudin, "Meta-requirement method towards analyzing completeness of requirements specification," in Advances in Intelligent Systems and Computing, 2019, vol. 881, pp. 444-454.

[8] M. I. U. Ong and M. A. Ameedeen, "User Requirement Validation: Challenge Exploration in Pre-project Execution," IOP Conf. Ser. Mater. Sci. Eng., vol. 769, 2020.

[9] M. I. U. Ong, M. A. Ameedeen, Z. R. Azmi, and I. E. Kamarudin, "Systematic Literature Review: 5 Years Trend in the Field of Software Engineering," Adv. Sci. Lett., vol. 24, no. 10, pp. 7278-7283, Jul. 2018.

[10] M. I. U. Ong and M. A. Ameedeen, “Approaches in Creating Meta-requirement: A Systematic Literature Review," IOP Conf. Ser. Mater. Sci. Eng., vol. 769, 2020.

[11] J. G. Walls, G. R. Widmeyer, and O. A. El Sawy, "Building an Information System Design Theory for Vigilant EIS," Inf. Syst. Res., vol. 3, no. 1, pp. 36-59, 1992.

[12] P. Meier, J. H. Beinke, C. Fitte, J. Schulte to Brinke, and F. Teuteberg, "Generating design knowledge for blockchain-based 
access control to personal health records," Inf. Syst. E-bus. Manag., pp. 1-29, Aug. 2020.

[13] J. Schjerlund, M. R. P. Hansen, and J. G. Jensen, "Design principles for room-scale virtual reality: A design experiment in three dimensions," in Lecture Notes in Computer Science (including subseries Lecture Notes in Artificial Intelligence and Lecture Notes in Bioinformatics), vol. 10844 LNCS, Springer, Cham, 2018, pp. 3-17.

[14] H. Guo, R. Brown, and R. Rasmussen, "A theoretical basis for using virtual worlds as a personalised process visualisation approach," in Lecture Notes in Business Information Processing, 2013, vol. 148 LNBIP, pp. 229-240.

[15] Y. Lu and T. Käkölä, "An Information Systems Design Product Theory for Integrated Requirements, Test and Defect Management Systems," in Proceedings of the Annual Hawaii International Conference on System Sciences, 2012, pp. 55165525.

[16] Y. Lu and T. Käkölä, "An Information System Design Product Theory for Integrated Order, Transportation and Warehouse Management Systems," Proc. Annu. Hawaii Int. Conf. Syst. Sci., pp. 3717-3726, 2013.

[17] P. Forselius and T. Käkölä, "An information systems design product theory for software project estimation and measurement systems," in Proceedings of the 42nd Annual Hawaii International Conference on System Sciences, HICSS, 2009.

[18] T. Käkölä, M. Koivulahti-Ojala, and J. Liimatainen, "An Information Systems Design Theory for Integrated Requirements and Release Management Systems,” 2009 42nd Hawaii Int. Conf. Syst. Sci., pp. 1-10, 2009.

[19] UMP, PERATURAN AKADEMIK PROGRAM DIPLOMA DAN SARJANA MUDA SEPENUH MASA UMP. 2019.

[20] J. Venable, J. Pries-Heje, and R. Baskerville, "FEDS: A Framework for Evaluation in Design Science Research," Eur. J. Inf. Syst., vol. 25, no. 1, pp. 77-89, 2016.

[21] G. Spanoudakis and A. Zisman, “SOFTWARE TRACEABILITY: A ROADMAP,” World Scientific Publishing Co, 2005. 